\title{
Direct and Indirect Effects of Independents Variables on Return on the Total Assets of Composite Cotton Sector-An Analytical Study in Indian Textile Companies
}

\author{
A. Dharmaraj and Dr.S. Sivakumar
}

\begin{abstract}
Textile industries in India are playing a vital role in the economy of the country. In recent years, it has also become an important factor for employment. It has made a remarkable impact in the economic growth of the nation through its growth and development in the past few years. This paper presents an analytical study of Indian textile industries. The direct and indirect impacts of independents variables on return on the total assets of composite cotton sector have been thoroughly analyzed. This study mainly focuses on the financial impact of the selected industries. This investigation gives a overall financial performance of the Indian textile industries.
\end{abstract}

Keywords--- Indian Textile industry, CMIE, CTR

\section{INTRODUCTION}

I NDIAN Textile Industry is most important textile industries in the universe. A new revolution started in 1991; it was economic liberalization of Indian economy. Indian Textile industry becomes largest industry in the world which got more thrust from Economy. It mostly depends upon textile manufacturing and export. It play vital role in economy of the country. Foreign exchange through textile exports got $30 \%$ earnings for India.

In additional, the textile industries of India also offer nearly 14 per cent of the total industrial production of the country. It also supplies around 3 per cent to the GDP (Gross Domestic Product) of the country. The Indian textile industry is also the major in the country in terms of produce employment opportunities, at present creates employment opportunity for more than 35 million people. It opens up scope for other supplementary sectors and produces jobs in its own industry.

\section{Statement Of the Problem}

In early $1950 \mathrm{~s}$, only $10 \%$ GDP was used for India's manufacturing sector account but currently it accounts for 19\%. In 1990s the country embraced the new economic

A. Dharmaraj, Assistant Professor, Department of Management, Karpagam University Coimbatore.

Dr.S. Sivakumar, Assistant Professor, Department of Commerce, Karpagam University, Coimbatore.

DOI: 10.9756/BIJIEMS.4252 policy before to that the sector extremely protected from internal and external competition.

At present, the growth is expected to be around US\$ 52 billion and is projected to be around US\$ 115 billion by the year 2012. The present domestic market of textiles in India is predictable to increase to US\$ 60 billion by 2012 from the current US\$ 34.6 billion. The textile exports of the country were around US\$ 19.14 billion in 2006-07, which saw a stiff rise to reach US\$22.13 in 2007-08. The share of exports is also predictable to increase from $4 \%$ to $7 \%$ by 2012 .

Beside this background, it is very significant to investigate the financial performance of the manufacturing sector after liberalization to show how the liberalization had really led to an development in the growth performance of the sector, lifting of the import restrictions of the Multi-Fiber Arrangement (MFA), since 1st January 2005 under the World Trade Organization (WTO) Agreement on Textiles and Clothing.

\section{A. Objectives of the Study}

Mainly, this study aims to test and analyze the selected seven companies from the selected one sector for financial performance. To accomplish the above status, this study has the following objectives.

Analyze and compare the financial performance of the selected textile companies in India. To offer proposal on the basis of answer for the improvement of textile companies in India.

\section{B. Significance of the Study}

According to the CMIE (Centre for Monitoring Indian Economy), the textile industry has a significant occurrence in the economic life of India. It plays a critical role through its contribution to industrial output, employment production and export earnings of the country. The sales, productivity and profitability purpose in the textile industry differs from the other Industries.

Although many studies in this direction have been conducted, the present one will be of great significance to many. It will be helpful in understanding the pattern and the structure of the financial variables of leading companies apart from identifying the financial relationship of companies with their respective Industry. 


\section{Hypotheses of the Study}

Keeping the above objectives, the following hypothesis has been formulated and tested during the study period. The growth in working funds contributes much towards the profitability of the textile companies in India. The decrease in debtors has an indirect and the positive impact on the profitability of the company. There is positive relationship between inventory turnover ratio and profitability. There is positive relationship between fixed assets turnover ratio and profitability.

\section{RESEARCH METHODOLOGY}

The financial performance of textile industries can be measured by a number of indicators. Among these, profitability is the most important and reliable indicator as it gives a broad indication of the capability of textile industries to increase its earning.

\section{A. Research Design}

While concentrating on the organized sector of textile manufacturing industry, the present study has drawn a sample of thirty five companies, whose securities are regularly traded in Indian Stock Markets. Moreover, ready availability of the financial information for at least the past 10 years (without any changes in accounting and other practices) also contributed to the final selection of the samples. The study has drawn the sample units from the list of textile firms, whose securities are regularly traded, mostly in the organized sector.

\section{B. Sampling Design}

According to Prowess' corporate database developed by CMIE, (Centre for Monitoring Indian Economy) 871 organized companies are operating in the Indian Textile Industry. These organized companies are classified into 24 sectors under the Indian textile industry. In order to select the sectors to fulfill the purpose of study, only one sector has been selected, based on the average paid up capital of 10 years from 2000-01 to 2009-10. The selected sector includes 51 companies. Out of which only 7 companies are selected for the present study.

The selected sample companies are listed under the categories of the five selected sectors. The categorization of sample units has been provided in Table 1.1.

Table -1.1: Selected Textile Companies in the Present Study

\begin{tabular}{|c|c|}
\hline \multirow{4}{*}{ SECTOR } & $\begin{array}{c}\text { NAME OF THE SELECTED } \\
\text { COMPANIES }\end{array}$ \\
\hline \multirow{4}{*}{$\begin{array}{c}\text { Amol Dicalite Ltd } \\
\text { COMPOSITE }\end{array}$} & $\begin{array}{c}\text { Binny Ltd } \\
\text { COTTON }\end{array}$ \\
\cline { 2 - 2 } & $\begin{array}{c}\text { Juggilal Kamilapat Cottons Spg. } \\
\text { \& Wvg Mitsinghji Spg \& }\end{array}$ \\
\cline { 2 - 2 } & Marathon Nextgen Realty Ltd \\
\cline { 2 - 2 } & Sree Karpagambal Mills Ltd \\
\cline { 2 - 2 } & Victoria Mills Ltd \\
\hline
\end{tabular}

\section{Selection of Period for the Study}

The period for this study covered ten years from 2000-01 to 2009-10 and the essential data for this period have been collected from seven companies. The financial year runs from $1^{\text {st }}$ April to $31^{\text {st }}$ March every year.

\section{Statistical Tool Used}

In order to identify the prominent factors responsible for the profitability of textile industries, and also to measure the extent of influence of the independent variables on the dependent variable, the following tool were applied by the researcher:

\section{Path ANalysis}

The process of path analysis depends largely on a series of multiple regression analyses with an added assumption of causal relationship between independent and dependent variables. The fundamental working of path analysis is that any correlation coefficient between two variables or a gross or overall evaluation of empirical relationship can be decomposed into a sequence of segments: separate paths of influence resulting in chronologically intermediate variable to which both correlated variables have links. The direct and indirect influence of independent variables on the dependent variable is computed.

\section{LIMITATIONS OF THE STUDY}

Some of the unavoidable limitations of the present work are as follows:

Financial information collected for the present study is entirely secondary in nature. In such a scenario, the investigation takes into consideration all the drawbacks inbuilt with the secondary data and financial data. The study is limited to certain companies and selected sectors only for the period of ten years.

\section{ANALYSIS AND INTERPRETATIONS}

It can be observed from table that between the AMOL composite cotton sector for the period of 2000-01 -2009-10, the following independent factors have significant correlation coefficient with the ratio of return on total assets; $\mathrm{X}_{10}$ (Inventory to total assets ratio) -1.24, $\mathrm{X}_{12}$ (Creditors Turnover Ratio) 0.460, $\mathrm{X}_{17}$ (Debtor turnover ratio) 0.166, $\mathrm{X}_{23}$ (ROCE) -0.191 and other variables have contributed directly towards the ratio of return on total assets whereas it is also indirectly reasonable when the respective variable is integrated with other indirect effects but it is observed to be statistically not significant.

Table 2.1: Direct and Indirect Affects of Independents Variables on Return on the Total Assets of Composite Cotton Sector

\begin{tabular}{|c|c|c|c|c|c|c|c|}
\hline S. & AM & BIN & JA & M & JUG & MARAT & SHREE \\
NO & NY & $\begin{array}{c}\text { SH } \\
\text { RI }\end{array}$ & GIL & HAN & $\begin{array}{c}\text { VICTO } \\
\text { GAM }\end{array}$ & RIA \\
\hline $\mathrm{X}_{2}$ & & & & & & & -.593 \\
\hline $\mathrm{X}_{3}$ & & .473 & & & & & \\
\hline $\mathrm{X}_{7}$ & & & & & .582 & & \\
\hline $\mathrm{X}_{10}$ & - & & & & & & \\
\hline $\mathrm{X}_{11}$ & & & - & & & & \\
\hline $\mathrm{X}_{12}$ & .460 & & & & & & \\
\hline $\mathrm{X}_{13}$ & & & .33 & & & & \\
\hline
\end{tabular}




\begin{tabular}{|l|c|c|c|c|c|c|c|}
\hline & & & 8 & & & & \\
\hline $\mathrm{X}_{16}$ & & & & .638 & & & \\
\hline $\mathrm{X}_{17}$ & .166 & .555 & & & & & .469 \\
\hline $\mathrm{X}_{18}$ & & & & & & -.759 & \\
\hline $\mathrm{X}_{23}$ & - & & & & & & \\
\hline
\end{tabular}

Finally, an insight this reveals that the variables $X_{12}$ and $X_{17}$ contributes towards profitability and $X_{10}, X_{23}$ reduces the profitability position. In Binny ltd, $\mathrm{X}_{3}$ (Net income to total debts) .473 and $\mathrm{X}_{17}$ (Debtor turnover ratio) .555 contribute towards profitability. In Jamshri Ranjitsinghji Spg \& Wvg Mills Co Ltd, $\mathrm{X}_{13}$ (Debt to total assets) .338 contributes towards profitability and $\mathrm{X}_{11}$ (Operating profit to Sales) -1.151 reduces the profitability position and for Juggilal Kamlapat Cottons Spg. \& Wvg Mills Co Ltd , $\mathrm{X}_{16}$ (Inventory turnover ratio) .638 contributes towards profitability.

In Marathon Nextgen Realty Ltd, $\mathrm{X}_{7}$ (Working Capital to total assets) .582 and $\mathrm{X}_{11}$ (Operating profit to Sales) .559 contribute towards profitability and for Sree Karpagambal Mills Ltd, $\mathrm{X}_{18}$ (Debt-Equity Ratio) -.759 reduces the profitability position and for Victoria Mills Ltd, $\mathrm{X}_{17}$ (Debtor turnover ratio) .469 contributes towards profitability and $\mathrm{X}_{2}$ (Return on equity) .593 reduces the profitability position.

\section{SUGGestions}

In Composite cotton sector, the term inventory to total assets and return on capital employed of Amol Dicalite Ltd, operating profit to sales of Jamshri Ranjitsinghji Spg \& Wvg Mills Co Ltd, Debt euity ratio of Sree Karpagambal Mills Ltd, and return on equity of Victoria Mills Ltd which causes for reduction in their profitability of concerns. Hence these companies are advised to enhance their profitability position through proper mix of debt and equity.

\section{CONCLUSION}

The intrinsic benefits and importance of the textile industry have been witnessed in the past few decades. Textile industries have faced several periods of adversity with the dip in the growth chart. In recent years, many alterations have been seen in the World trading system that endangered the stability of the textile industry and created an atmosphere of uncertainty and turbulence in the industry. But it is also a fact that turbulence is necessary for any change in the system. It has become an essential factor that there is a requirement to bring about technological enhancement, structural alterations, liberalisation from controls and regulations, increased productivities of labour and machine and reliable quality assurance systems. If there is insecurity inherent in the globalised economy, there are also chances - opening up of huge markets to Indian textiles and Indian clothing that were earlier closed or regulated Indian textile industries utilizes this option of of free trade and secure its well deserved place in the international textile arena.
ANNEXURE-1 LIST OF DEPENDED AND INDEPENDENCE VARIABLES

Y Return on total assets

$\mathrm{X}_{1} \quad$ Return on sales

$\mathrm{X}_{2} \quad$ Return on equity

$\mathrm{X}_{3} \quad$ Net income to total debts

$\mathrm{X}_{4} \quad$ Cash to total assets

$\mathrm{X}_{5} \quad$ Quick assets to total assets

$\mathrm{X}_{6} \quad$ Current assets to total assets

$\mathrm{X}_{7} \quad$ Working Capital to total assets

$\mathrm{X}_{8} \quad$ Cash to current liabilities

$\mathrm{X}_{9} \quad$ Quick ratio

$\mathrm{X}_{10} \quad$ Inventory to total assets

$\mathrm{X}_{11} \quad$ Operating profit to Sales

$\mathrm{X}_{12} \quad$ Creditors turnover ratio

$\mathrm{X}_{13} \quad$ Debt to total assets

$\mathrm{X}_{14} \quad$ Total assets to Equity

$\mathrm{X}_{15} \quad$ Net fixed assets to equity

$\mathrm{X}_{16} \quad$ Inventory turnover ratio

$\mathrm{X}_{17} \quad$ Debtors turnover ratio

$\mathrm{X}_{18} \quad$ Debt-Equity Ratio

$\mathrm{X}_{19} \quad$ Current ratio

$\mathrm{X}_{20} \quad$ Long term Debt-Equity ratio

$\mathrm{X}_{21} \quad$ Fixed assets turnover ratio

$\mathrm{X}_{22} \quad$ Interest cover Ratio

$\mathrm{X}_{23} \quad$ Return On Capital Employed(ROCE) 